\section{Igor Mel'čuk}

Observatoire de linguistique Sens-Texte Université de Montréal

(iD https://orcid.org/0000-0002-4520-0554

\section{Clichés \\ and pragmatemes}

\title{
Abstract
}

In order to properly classify the phraseme (that is, a constrained, or non-free, expression) No parking, a universal typology of lexical phrasemes is proposed. It is based on the following two parameters:

- The nature of constraints

- Lexemic phrasemes: the expression is constrained with respect to freely constructed meaning.

- Semantic-lexemic phrasemes: the expression is constrained/non-constrained with respect to the meaning constrained by the conceptual representation.

- Pragmatemes: the expression is constrained with respect to pragmatic conditions, that is, to the extralinguistic situation of its use (in a letter, on a street sign, on a package of perishable food).

- The compositionality

The expression can/cannot be represented as regular "sum" of its components.

As a result, we have, firstly, the following major classes of lexical phrasemes:

1) Non-compositional lexemic phrasemes: idioms ('COLD FEET', 'SHOOT THE BREEZE')

2) Compositional lexemic phrasemes: collocations (rain heavily, pay a visit)

3) Non-compositional semantic-lexemic phrasemes: nominemes (BIg DipPer, New South Wales)

4) Compositional semantic-lexemic phrasemes: clichés (See you tomorrow! | Absence makes the heart grow fonder.)

For clichés, the least-studied class of phrasemes, a more detailed classification is proposed (as a function of the type of their denotation).

Secondly, each phraseme (except a nomineme) and each lexemes can be pragmatically constrained, i.e. a pragmateme: 'FALL out!' (idiom; a military command) | Take aim! (collocation; a military command) $\mid$ Emphasis mineladded (cliché; in a printed text) $\mid$ Rest! (lexeme; a military command).

\section{Keywords}

English, phrasemes, lexical phrasemes, idioms, collocations, semantic-lexical phrasemes, nominemes, clichés, pragmatemes 
1. Stating the problem: What type of phraseme is the expression No parking? . . . . . 10

2. Two major families of phrasemes: lexical phrasemes vs. semantic-lexical phrasemes . . 11

2.1 Lexical phrasemes: idioms and collocations . . . . . . . . . . . . . . . . . 11

2.2 Semantic-lexical phrasemes: nominemes and clichés . . . . . . . . . . . . . . 12

3. Pragmatemes . . . . . . . . . . . . . . . . . . 16

4. Solving the problem: The expression No parking is a cliché pragmateme . . . . . . . 18

Acknowledgments . . . . . . . . . . . . . . . . . . . . . . . 19

References . . . . . . . . . . . . . . . . . . . . . . . 19

\section{Stating the problem: What type of phraseme is the expression No parking?}

PARKING: Who in North America does not know this sign? But who has asked himself what type of expression is found on it? What indeed is the expression No parking? It is by no means a free phrase: one does not normally see on traffic signs in the US, Canada or Great Britain such expressions as Parking forbidden, Parking prohibited, Interdiction to park or Do not park, although they mean exactly the same and are perfectly grammatical; if one of these phrases were found on a traffic sign, you would immediately conclude that its author is not a native speaker of English. Note that in different languages the corresponding phrases on traffic signs are different:

$\begin{array}{lll}\text { French } & \text { Défense de stationner } & \text { 'Interdiction to park' } \\ \text { Spanish } & \text { Prohibido aparcar } & \text { 'Prohibited to.park' } \\ \text { Italian } & \text { Divieto di parcheggio } & \text { 'Prohibition of parking' } \\ \text { Greek } & \text { Apagoreúetai è státhmeusēe } & \text { 'Is.being.forbidden the parking' } \\ \text { German } & \text { Parken verboten } & \text { 'Parking forbidden' } \\ \text { Russian } & \text { Stojanka zapreščena } & \text { 'Car.stand is.prohibited' } \\ \text { Polish } & \text { Zakaz parkowania } & \text { 'Prohibition of.parking' } \\ \text { Hungarian } & \text { Parkolni tilos } & \text { 'To.park forbidden' } \\ \text { Turkish } & \text { Park yapılmaz } & \text { 'Parking is.not.done' } \\ \text { Indonesian } & \text { Dilarang parkir } & \text { 'Is.forbidden park' }\end{array}$

From this, one has to conclude that No parking is a phraseme: a non-free that is, constrained - multiword expression. However, it is compositional therefore, it is not an idiom. It is not a collocation, either: the lexeme that means 'to.park/parking' does not require a particular collocate, since all the expressions Parking forbidden, Parking prohibited, Interdiction to park, Do not park etc. are absolutely correct as far as English lexical co-occurrence goes: they are only bad on a traffic sign. The question which the present paper answers is, then, as follows:

$\|$ What type of phraseme is the expression No parking? 


\section{Two major families of lexical phrasemes: lexemic phrasemes vs. semantic-lexemic phrasemes}

In the analysis which follows only lexical phrasemes are considered - to the exclusion of morphological and syntactic phrasemes.

The problem with No parking is due to the following fact: both best-known families of phrasemes - idioms and collocations - are based on one level of constraints: namely, between the linguistic meaning and its lexical expression. However, as the example of No parking shows, there are more families of phrasemes underlain by two more types of constraints: on the one hand, those operating in the transition between the conceptual content to be expressed and the corresponding linguistic meaning (i.e. a semantic representation) and, on the other hand, those coming, so to say, perpendicularly — from the special situation in which the given phraseme is used. (For the theoretical framework within which the following discussion is conducted, see, for instance, M el'č u k 2012, 2013, 2015a and 2015b: Ch. 16.)

\subsection{Lexical phrasemes: idioms and collocations}

Idioms and collocations are characterized by the following property:

\|1) their meaning (which is their signified) is freely chosen by the Speaker, but

|| 2) their lexical expression (which is their signifier) is constrained - either totally (for idioms) or partially (for collocations) — with respect to their meaning. ${ }^{1}$

In other words, the meaning of an idiom or a collocation is freely selected, but is not freely expressed. Here are formal descriptions of an idiom and a collocation at the semantic, deep-syntactic and surface-syntactic levels of linguistic representation.

\section{An idiom}

$[X$ 's] 'COLD FEET' [about Y]: 'X's intense apprehension' about $\mathrm{Y}$ '

[ ' 'apprehension' $^{1}=$ 'fear of future evil' vs. 'apprehension' ${ }^{2}$ = 'legal seizure'.

Was it a simple case of his cold feet about the ceremony or something more?

Sally got cold feet at the last moment and called off the wedding.

Leaving Ireland wasn't easy, and I had cold feet about it a couple of times.

${ }^{1}$ The signified of a sign is not necessarily a meaning - it can be a syntactic or communicative indication. For the notion of linguistic sign and its components, see, for instance, M el' č u k 2012: $25 f f$. 

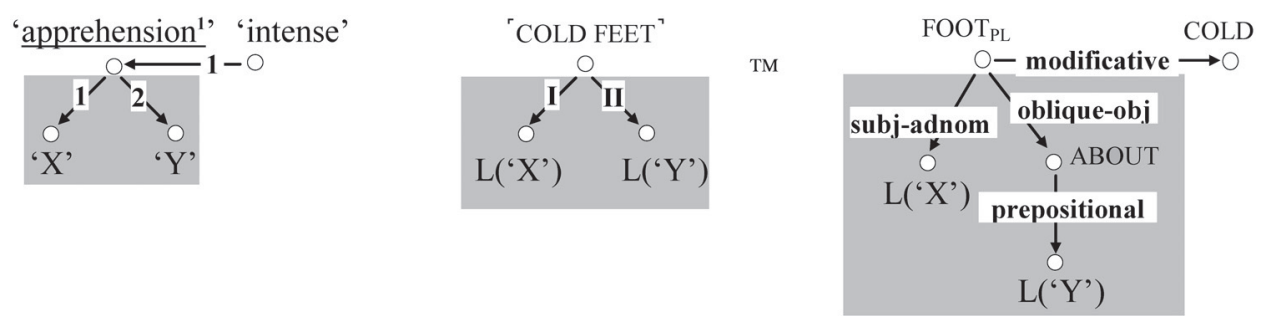

The complex meaning 'intense apprehension", (two semantemes) is expressed as a whole by the phrase 'COLD FEET" (which occupies one node in the deep-syntactic structure); neither component of this phrase can be selected by the Speaker independently of the other.

\section{A collocation}

[It] rains hard 〈heavily〉.

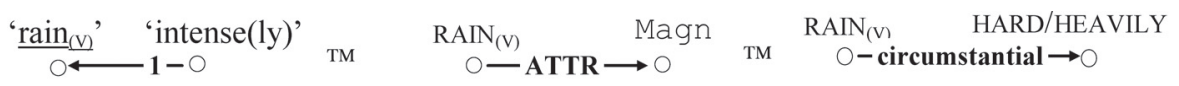

The complex meaning '[it] rains intensely' is expressed component-by-component, that is, compositionally: ' $\operatorname{rain}_{(\mathrm{V})}{ }^{\mathrm{TM}} \mathrm{RAIN}_{(\mathrm{V})}$, and 'intensely' ${ }^{\mathrm{TM}} \mathrm{HARD} /$ HEAVILY. The lexeme $\operatorname{RAIN}_{(\mathrm{V})}$ is selected by the Speaker freely - just for its meaning. However, the selection of lexeme HARD or HEAVILY is constrained: it is selected by the Speaker in order to express the meaning 'intensely' as a function of $\operatorname{RAIN}_{(\mathrm{V})}$ : 'intensely' with CAMPAIGN $_{(\mathrm{V})}$ is expressed by VIGOROUSLY, with APPLAUD $_{(\mathrm{V})}$ - by LOUDLY and WARMLY, and with RESPECT $(\mathrm{V})$ - by DEEPLY, etc. (This is a well-known phenomenon of collocation, described, in our framework, by means of lexical functions.)

An idiom and a collocation have their lexemic expression constrained in the transition between a meaning and its surface expression; therefore, idioms and collocations can be called lexemic phrasemes.

\subsection{Semantic-lexemic phrasemes: nominemes and clichés}

The commonest of phrases What time is it? is not free: one cannot replace it, for instance, with *How much time is it? (calquing the Russian Skol'ko vremeni?) or *What hour/o'clock is it? (modeled after the French Quelle heure est-il?). What time is it? is a phraseme, but not a lexemic phraseme: its lexical expression is not constrained with respect to its meaning ('I want you to tell me what time it is'). What is constrained is the selection of the meaning itself: an English speaker is not free to express another - even if fully equivalent - meaning, such as *'I want you to tell me how much time it is' or *'I want you to tell me what hour it 
is.' We are in presence of the second major family of lexical phrasemes: semanticlexemic phrasemes.

A semantic-lexemic phraseme has its meaning constrained with respect to a deeper representation of the extralinguistic reality the Speaker wants to talk about, namely, to the conceptual representation [= ConceptR]. (Its lexemic expression can both be constrained or free with respect to its meaning. ${ }^{2}$ ) The ConceptR of a chunk of extralinguistic reality is a reflection of this chunk in the psyche of the Speaker; this reflection is supposed to be 1) discrete (i.e. symbolic), 2) as objective as possible and 3) maximally independent from the Speaker's language. Since within the Meaning-Text approach the ConceptR is still in its babyhood, the illustration offered below is rather primitive. ConceptR expressions will be printed in Courier New and included in «" quotes.

Let us stick to our "time of the clock" example, so that we could use the common time indication as the ConceptR for the time expressions.

Take for instance, the moment marked «8:43». The corresponding English meaning for this is ' 17 minutes to 9 o'clock' (seventeen to nine), while in French a different meaning is obligatory: '9 o'clock minus 17 minutes' (neuf heures moins dix-sept). In Russian, the corresponding meaning is still different: '9 o'clock without 17 minutes' (bez semnadcati devjat'). As is obvious, in these three cases the starting meaning is constrained. ${ }^{3}$ (In Russian, the lexemic expression of this phrase is also constrained with respect to its meaning: the prepositional group bez semnadcati 'without 17 ' must precede its syntactic governor, although, as a general rule, in Russian a prepositional group follows its governor.)

To sum up: The phrase seventeen to nine and all similar phrases are semanticlexemic phrasemes; here, the selection constraints are applied in the transition between a ConceptR and the corresponding semantic representation $[=\mathrm{SemR}]$ and in some cases also between the SemR and its lexical expression.

Semantic-lexemic phrasemes fall, in their turn, into two classes: non-compositional and compositional ones.

- Non-compositional semantic-lexemic phrasemes are called nominemes; these are multilexemic proper names:

MARK TwaIN [a famous American writer] JEHOVAH'S WITNESSES [a religious denomination] THE NIGHT OF LONG KNIVES [Hitler's murderous purge of political opponents in 1934] THE Big DiPPER [a well-known group of stars]
NEW JERSEY [a state in the USA]

Washington TeRrace [a town in the USA]

New South Wales [a state in Australia]

BIG BANG [the cosmic explosion that marked the beginning of the Universe]

${ }^{2}$ The semantic-lexemic phrasemes whose lexemic expression is free are rather rare. Such are, for instance, the phrasemes on the signs Turn off (Switch off, Close) your cell (mobile) (phone); note that on signs they do not write "No cell phones or 'The use of cell phones is not allowed. (These phrasemes are pragmatemes, see Section 3).

${ }^{3}$ The problem of constrained meanings - that is, linguistically correct/incorrect semantic structures - is discussed in Iordanskaja \& Mel'čuk 2009. 
The nominemes belong rather to an encyclopaedia than to a linguistic lexicon, and in what follows they will be left aside.

- Compositional semantic-lexemic phrasemes are called clichés; they include a motley set of expressions:

\section{- Everyday-speech formulas}

See you soon/later/tomorrow/...!

How are you?

What is your name?

- Have a nice day! - You too.

Happy birthday to you!

Say again (please).

I am sorry.

The last thing $X$ needs is $Y$.

How can I help you?

so to say/speak

\section{— "Technical"-text formulas}

to put it differently

in what follows

to sum up

leave aside

$X$ has to admit that ...

\section{- Commands}

Full speed ahead!

\section{- Proverbs and sayings}

Adversity and loss make a man wise.

\author{
May I come in? \\ Come in! \\ How old are you? \\ Sit down, please! \\ three and $a$ half [3.30: a moment of time] \\ Feel better soon! \\ I couldn't agree more. \\ What was it? \\ $X$ has nobody to blame but himself. \\ you are welcome \\ in other words \\ to give an example \\ in sharp contrast [to $Y]$ \\ to begin with \\ if any \\ Let it be emphasized that ... \\ All hands on deck! \\ All good things come to an end.
}

Being compositional, a cliché is not a lexical unit, and therefore it does not have its own lexicographic entry. It is described in the entry of its lexical anchor - a word that identifies the informationally important semanteme in the clichés meaning. A cliché can have more than one lexical anchor; it is possible for a lexical anchor to not appear physically in the corresponding cliché. Thus, the cliché Happy birthday! has two lexical anchors: birthday and good wish; it is described in the lexical entries of the nouns BIRTHDAY and $\mathrm{WISH}_{(\mathrm{N})}$.

The lexicographic description of a cliché has to include a component absent from the lexicographic description of a lexemic phraseme, namely - the corresponding ConceptR, for instance:

\section{English}

«I know that it is the

day of your birth, and

I want to tell you

тм 'I wish you to have a happy birthday'

тм Happy birthday!

something nice» 


\section{Russian}

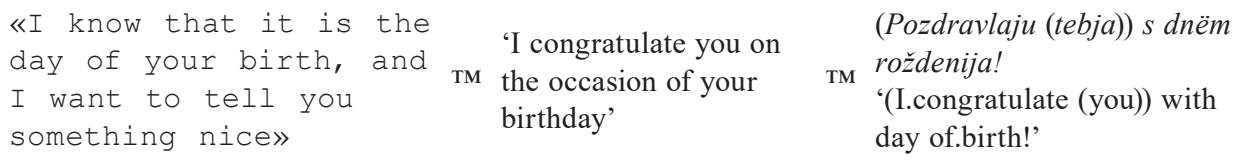

In order to demonstrate in a clearer way the "gap" between the ConceptR (= the intended informational content) and the SemR (= the linguistic meaning) of a cliché, we can consider the cliché Break a leg!, used to wish a performer "good luck" on the scene:

«I wish you a successful тм 'I wish you to break a leg' тм Break a leg!
performance»

Using this cliché, the Speaker expresses his wish of a successful performance for his Addressee, but lexicalizes a "ritualized" meaning, a kind of secret password. ${ }^{4}$

Clichés are further divided into four subclasses, according to the nature of their denotation ${ }^{5}$ (M e l' č u k 2015a: 69-80); these subclasses are distinguished by two parameters:

- The denotation of the cliché under consideration is concrete $(\approx$ objective, physical) or abstract ( $\approx$ subjective, mental);

- The denotation is specific (= an individual, in the logical sense of the term) or generic ( $=$ a class of individuals).

- If the denotation is concrete, it is:

1) either specific, i.e., an individual, or a particular definite entity of the "outer world," such as a given object or a being, a particular event, a specific substance;

2) or generic, i.e., a class of individuals.

- If the denotation is abstract, it also is:

3) either specific, i.e., an expression of the Speaker's particular wish, intention, attitude, feeling (a ritualized speech act) or a simile concerning a particular situation;

4) or generic, i.e., a general statement by the Speaker about the world (concerning a class of situations).

${ }^{4} \mathrm{Cf}$. the following well-known joke:

A knock on X's door.

$\mathrm{X}$ : - Who is there?

Y: - Are you selling a wardrobe Louis XIV?

$\mathrm{X}$ : - Oh Jesus, how many times have I to repeat it?? The spy lives two stories up.

The linguistic meaning of Y's question is exactly what it says; however, it is a convened password to express the content «I am one of yours».

${ }^{5}$ Remember that the referent of a sign $\mathbf{s}$ used in a text is an entity or a fact of real world to which $\mathbf{s}$ refers; the denotation of $\mathbf{s}$ stored in a lexicon is the infinite set of its possible referents. 
Thus, we obtain four subtypes of clichés:

Nickname clichés: City of light 'Paris', Eternal city 'Rome', The Great Helmsman 'Mao Zedong', The Queen of the Sciences 'mathematics'

Termemes: $\quad$ Foreign Office, tea rose, Alzheimer disease, bottlenose WHALE

Formulemes: $\quad$ I am sorry. $\mid X$ has nobody to blame but himself. $\mid$ to say the least

Sentencemes: $\quad$ Beggars can't be choosers. | Big thunder, little rain.| Never speak ill of the dead.

I will not go into more details concerning clichés, since my main objective in this paper is to charact - erize a special subtype of phrasemes: pragmatemes. They will be considered in the next section; now let me sum up what I have said so far about phrasemes in Figure 1:

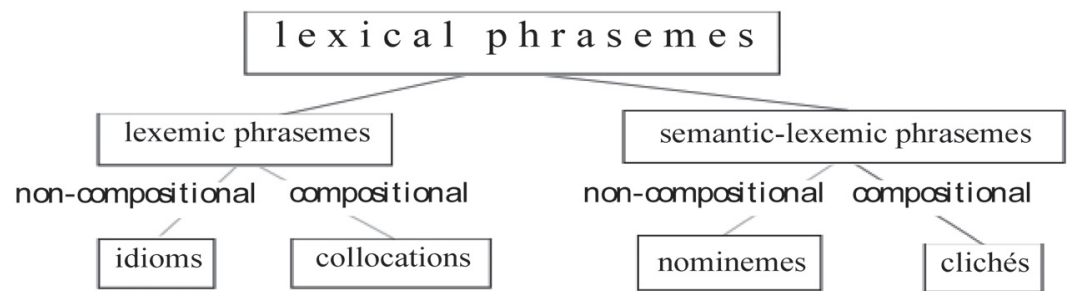

Fig. 1. Four Major Classes of Phrasemes

\section{Pragmatemes}

Now, I can give a half-answer to the question asked at the end of Section 1:

\| The phraseme No parking is a cliché.

No parking is a cliché since it is fully constrained - semantically (in the construction of its meaning) and lexically (in the construction of its lexical expression), while being compositional.

However, it features an additional particularity: it is also constrained by the special situation of its use; more specifically, on a traffic sign, in order to express the meaning 'We forbid you to park your car here' the use of the cliché No parking is obligatory. In other words, one can say that this cliché is constrained pragmatically.

Let it be emphasized: the special situation sit in which for a given meaning a particular cliché must be used and which thereby pragmatically constrains it is 
different from the situation SIT described by the cliché. Thus, when you say to your friend Merry Christmas!, this cliché describes the situation SIT of Christmas, good wishes, etc., but there is no special situation sit of its use: you are speaking to your Addressee and use the expression Merry Christmas! in quite a normal, rather trivial situation of linguistic communication. But when this cliché is printed on a Christmas card, the sit of its use is special - namely, [on a greeting card]. This means that on a greeting card the use of the pragmateme Merry Christmas! is obligatory (with a few possible alternatives), but it can be used outside this situation as well. This is true for many, if not all, pragmatemes.

As any phraseme (with the exception of nominemes), a pragmateme must be described in the lexicon; as a cliché, a multilexemic pragmateme has to be described within the lexical entry of its anchor. A pragmateme's lexicographic description has to include one component more than other clichés - namely, an indication of the special situation of its use; cf::

Best before [Y]

[on a package of perishable food to

Wrong way

Do not enter

Drive slow(ly)

Beware of (the) dog

For rent

Only authorized persons to enter this area

Wet floor

Store/Business hours

Do not disturb

Season's Greetings

Merry Christmas!

Sincerely yours

To whom it may concern

Emphasis mineladded

To be continued

be sold]

[on a traffic sign]

[on a traffic sign]

[on a traffic sign]

[on a sign]

[on a sign]

[on a sign]

[on a sign]

[on a sign]

[on a door]

[on a card]

[on a card]

[in a formal letter]

[in an official letter]

[in a printed text]

[in a printed text]

However, not only clichés can be constrained pragmatically, i.e. by the special situation of their use. In fact, lexemes, idioms and collocations can also be:

Pragmatically constrained lexical entities (other than clichés)

- lexemes

ROGER!

[in a radio communication] REST!

Affirmative/Negative

[in a radio communication] $\mathrm{PULL} / \mathrm{PUSH}$

[a military command]

[on a door] 
— idioms

'At Ease!'

'HOLd THE LINE'

- collocations

Wet paint

Take aim!

Mission accomplished [a military command]

[in a telephone

communication]

[on a sign]

[a military command]

[in a military report]
'PRESENT ARMS!' [a military command]

'FALL OUT!' [a military command]

Use caution [on a traffic sign]

Watch your step [on a sign]

Wipe your feet [on a sign]

Therefore, it seems reasonable to posit the following definition.

Definition: pragmateme

II A pragmatically constrained lexical entity is called pragmateme.

The property "be pragmatically constrained" cuts across the three classes of phrasemes previously established (idioms, collocations, and clichés) plus the class of "ordinary" lexemes. As a result, we have four major subclasses of pragmatemes: lexeme pragmatemes, idiom pragmatemes, collocation pragmatemes, and cliché pragmatemes; cliché pragmatemes are by far most numerous and frequent.

A good review of pragmatemes in French and Spanish is found in two papers by X. Blanco (Blanco 2013 and 2014) and the monograph Blanco \& Mejri 2018.

\section{Solving the problem: The expression No parking is a cliché pragmateme}

Here, finally, is a full answer to the question about the phraseological status of the phrase No parking:

II The phrase No parking is a cliché pragmateme.

A reader familiar with the Meaning-Text approach will have noticed a change in the suggested terminology: Mel'č u k 2015a proposed to use the term pragmateme exclusively for cliché pragmatemes, calling all the other pragmatically restricted lexical entities just pragmatically restricted lexemes/idioms/collocations. The main reason for this was quantitative: cliché pragmatemes massively outnumber all other types of pragmatemes. However, over the last five years I changed my mind - under the gentle prodding by $\mathrm{A}$. Polguère (see, for instance, Fléchon, Frassi \& Polguère 2012 and Polguère 2016), who 
established that all pragmatemes, no matter whether lexemes, idioms, collocations or clichés, have the following two essential properties: ${ }^{6}$

- Semantically, a pragmateme is a signalative - a linguistic expression that does not represent logical propositions and therefore cannot be negated or questioned (Me l'č u k 2001: Ch. 3).

- Syntactically, a pragmateme is a clausative - a full utterance, equivalent to an independent clause (M el'č u k 2006: 40-41). Pragmatemes tend to feature special prosodies, which should be indicated in their lexicographic description.

This particularity makes all pragmatically constrained lexical entities into one well-defined class, which deserves a special name: pragmatemes.

\section{Acknowledgments}

The first sketch of the present paper was read and criticized by W. B a nyś, L. Iordanskaja, F. Louis, P. Mikhel and J. Milić ević; I cordially thank them all for their judicious remarks.

\section{References}

B la n c o, X., 2013: "Équivalents de traduction pour les pragmatèmes dans la lexicographie bilingue Français-Espagnol.” Lexicographica 29(1), 5-28.

B l a n c o, X., 2014: "Inventaire lexicographique d'une sous-classe de phrasèmes délaissée : les pragmatèmes.” Cahiers de lexicologie 104(1), 135-155.

B lanco, X. \& M ejri, S., 2018: Les pragmatèmes. Paris: Garnier.

Flé chon, G., Fra s si, P. \& Polguèr e, A., 2012: "Les pragmatèmes ont-ils un charme indéfinissable?" In: P. Lig a s, P. F r a s si, eds., Lexiques. Identités. Cultures. Verona: QuiEdit, 81-104.

Iordanskaja, L. \& Mel'čuk, I., 2009: "Linguistic Well-Formedness of Semantic Structures". In: D. B e ck, K. Gerdes, J. Milićević, A. Polguère, eds., Meaning-Text Theory 2009. Proceedings. Montreal, 177-187. See as well in: http:// olst.ling.umontreal.ca/pdf/ProceedingsMTT09.pdf.

Mel'č u k, I., 2001: Communicative Organization in Natural Language. The SemanticCommunicative Structure of Sentences. Amsterdam/Philadelphia: John Benjamins.

Me l'č u k, I., 2006: "Parties du discours et locutions." Bulletin de la Société de linguistique de Paris 101(1), 29-65.

${ }^{6}$ In fact Alain Polg u èr e showed that an important subclass of clichés, namely, formulemes, also features — albeit partially — the same properties. 
Me l'ču k, I., 2012: Semantics: From Meaning to Text. Vol. 1. Amsterdam/Philadelphia: John Benjamins.

Mel'ču k, I., 2013: Semantics: From Meaning to Text. Vol. 2. Amsterdam/Philadelphia: John Benjamins.

Me l'ču k, I., 2015a: "Clichés, an Understudied Subclass of Phrasemes." Yearbook of Phraseology 6, 55-86.

Me l’č u k, I., 2015b: Semantics: From Meaning to Text. Vol. 3. Amsterdam/Philadelphia: John Benjamins.

Polgu ère, A., 2016: Il y a un traître par minou : le statut lexical des clichés linguistiques. Corela. https://doi.org/10.4000/corela.4486. 